\title{
Developing Learners' Autonomy-Oriented Physics Teaching Materials to Enhance Students' Science Process Skills
}

\author{
Nadia $^{1}$, Mastuang ${ }^{2}$, Misbah $^{3}$, Mohd Ali Ibrahim ${ }^{4}$ \\ Universitas Lambung Mangkurat, Indonesia ${ }^{1,2,3}$, Universiti Teknologi Malaysia, Malaysia ${ }^{4}$ \\ nadia.baharuddin@icloud.com ${ }^{1}$, mastuang_pfis@ulm.ac.id ${ }^{2}$, misbah_pfis@ulm.ac.id ${ }^{3}$, p- \\ mali@utm.my ${ }^{4}$
}

Received: October $29^{\text {th }}, 2020$. Revised: December $30^{\text {th }}, 2020$. Accepted: January $7^{\text {th }}, 2021$

Keywords :

Learner Autonomy; Science

Process Skills; Teaching

Materials

\begin{abstract}
The unavailability of learner autonomy-oriented physics teaching materials which are capable of enhancing students' science process skills (SPS) of students is becoming a hindrance in one of the public high schools in Banjarmasin, as well as the lack of SPS in students. Thus, this study was carried out with the aim to produce learning materials oriented on learner autonomy orientation to enhance students' SPS properly. This was based on the validity, practicality, and effectiveness of the developed teaching materials in terms of learning outcomes in the students' cognitive and psychomotor domains. This research utilized research and development method with the use of the ADDIE development model (Analyze, Design, Develop, Implement, Evaluate). The trial subjects in this study consisted of 34 students of Grade $X$ in one of the public high schools in Banjarmasin. The data were obtained through validation sheets, lesson plan implementation sheets, SPS observation sheets, and learning outcomes tests $(L O T)$. The results indicated that the teaching materials developed were: 1) valid, based on the results of the validator's assessments with the average score of 3.35, categorized in the "valid" category; 2) practical, based on the implementation of lesson plan with the average score of 3.66 in the very good category; 3 ) effective, seen from the gain score obtained of 0.67 in the "medium" category; 4) SPS achievement of 72.17 in the "good" category. It is then concluded that the learner autonomy-oriented learning materials are feasible to be implemented in classroom activities.
\end{abstract}

\section{INTRODUCTION}

Science process skills (SPS) are compulsory skills which must be utilized by students when studying science. SPS are one of the skills needed by students to be able to develop their potentials [1] [2] [3]. SPS are basic skills that students need to have in the development of technological science in the 21 st 
century [4]. SPS developed in students contribute to improving their scientific achievement, critical thinking skills, and creativity [5] [6] [7]. There is a positive relationship between students' SPS and cognitive learning outcomes in high school biology material [8]. Important skills, such as critical thinking and problem solving, communication, collaboration, creativity, and innovation, are integrated skills which cannot be separated from SPS in science subjects [9].

Physics is one of the subjects in the science area which help nurture students' SPS [10]. This is due to the fact that almost all of the basic competencies of the core competencies in learning physics demand the classroom activities to use experiments which encourage students to become more active and innovative in learning. However, the facts show that the integration of SPS within physics subjects is still lacking. Based on the results of a preliminary study of Grade X students at one of the public high schools in Banjarmasin, there were very limited SPS skills of Grade X students, with the average score of their skills being 15.4 . Of all the students who took the test, only $57 \%$ were able to formulate a hypothesis. In addition, there were only roughly $5 \%$ of students who were able to identify variables, but most unfortunately, no students were able to analyze and conclude the results of the experiment.

The students' low SPS in physics can be caused by several factors, one of which refers to the learning methods applied by the teacher. Throughout the the learning process in the classroom, most physics subject teachers still highly depend on teacher-centered learning, which means that teachers become the main source of information or knowledge [11]. Learning science is not merely a process of transferring knowledge from teachers to students, but also the process of forming knowledge based on the students' initial knowledge which must be enriched through real activities that the students can experience, as well as their active involvement in the learning process [12]. Moreover, based on the results of an interview with a physics teacher at one of the public high schools in Banjarmasin, only a few physics teaching materials which could help nurture students' science process skills were available, for example, learner autonomy-oriented classroom activities.

Learner autonomy-oriented learning model refers to the learning model which is centered on students and is designed to give responsibility to the students slowly, as accordance to the level of development of students' abilities. This learning model is expected to affect students' independence in life, in which the teacher does not dominate but still guides, by integrating other learning models that are made varied in each meeting. Learner autonomy is a learning strategy that starts with the full role of the teacher to control the classroom, and then gradually shifting the role to the students, encouraging them to be more active and independent through choosing a learning model that is in accordance with the level of student development [13] [14] [15]. Learner autonomy is based on the idea that when students are more involved in the decision-making process, they tend to be more enthusiastic to study which makes them want to be more active in their learning [16].

The steps in learner autonomy learning apply a sequence of teacher-dominated learning models to learning models that are centered on the students. The use of learner autonomy learning model consists of several steps, namely the first model used in the learner autonomy stage, which is called as Direct Instruction (DI). At this stage, students are taught and guided to develop their SPS, then their SPS is further optimized by limiting the role of teachers in the learning process. At the same, time, the independence of students is increased through the second learning model, namely Guided Inquiry. At the end of the learning and teaching activities, Cooperative Learning type Group Investigation (GI) is carried out, in which at this stage students independently and actively apply the SPS which were taught and developed in the first and second learning models without any teacher guidance. The use of a model with a gradually increasing level is at the same time promoting the role of students to become more active. Learner autonomy is based on the idea that when students are involved in the decision-making process, they tend to be more enthusiastic to learn [17].

The topic of force and vibration motion is one of the materials suitable for learning with learner autonomy orientation. This material consists of three sub-topics, including the elasticity of objects, Hooke's law, and harmonic motion. The basic competence of force and vibration motion is to analyze the relationship between force and vibration in everyday life, which means that this material is suitable 
to be taught through experiment. The basic competence of force and vibration motion material is to analyze the relationship between force and vibration in everyday life, which also means that this material is suitable to be taught through experiment to nourish the science process skills of the students. Thus, due to its concrete nature, convenient to observe directly, and many of its phenomena that are related in everyday life, the use of this topic is expected to be able to easily enhance students' SPS. As stated by Hafizah [13] in her study, SPS can be a basic skill to solve daily life problem. Furthermore, learner autonomy model will give students a chance to actively participate during the learning process so that they can build skills that they need [18].

There is no research found yet on the development of teaching materials which are learner autonomyoriented learning model on the topic of force and vibration motion for Grade X in senior high school to enhance students' science process skills. Fatmah [19] developed learner autonomy-oriented teaching materials on the topic of light waves. Another research conducted by Salam et al [14] showed that the development of teaching materials could be utilized to enhance students' problem solving skills on the topic of waves. Therefore, it is necessary to carry out a research and development on learner autonomyoriented teaching materials for physics subject, focusing on the topic of force and vibration motions for Grade X students in senior high school with the hope that this solution will develop students' SPS gradually. In this study, there are several additions from the other research. At the beginning of the teaching materials, an explanation about SPS was given to students so that they could understand and emphasize which KPS was trained at certain times. Then, during the research, students were not immediately released to use teaching materials independently, but were still guided by reducing the level of guidance at each meeting. This is done to avoid students' surprise in using learner autonomy teaching materials.

To produce a good learner autonomy teaching materials, the teaching material must be assessed for its eligibility. Accordingly, this research aimed to describe the eligibility of the teaching materials which integrate the use of learner autonomy strategies on students' learning outcomes and science process skills when observed from the aspects of validity, practicality, and effectivity.

\section{METHOD}

This research is a research and development which uses the ADDIE development model, which is one of the development models with the name abbreviated from the first letter of each steps in the development steps, namely: Analyze, Design, Develop, Implement, and Evaluate. The brief explanation of the goals of each step is elaborated within Figure 1 below.

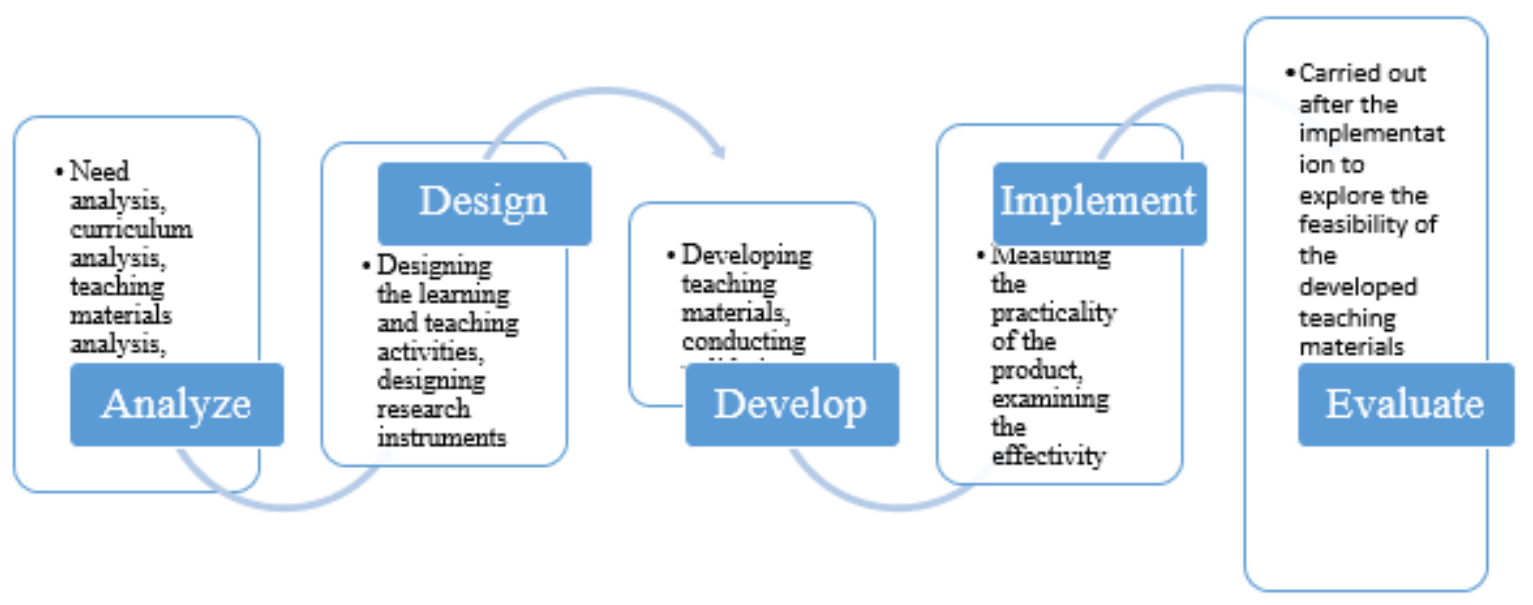

Fig 1. Steps of ADDIE model research [20] 
The trial subjects in this study consisted of 34 students of Grade $\mathrm{X}$ in one of the public high schools in Banjarmasin. The research instruments used include validation sheets for the teaching materials, lesson plan observation sheets, SPS observation sheets, and LOT (learning outcome tests). The feasibility of teaching materials are measured based on aspects of validity, practicality, and effectiveness of teaching materials, which is explained as follows.

The validity of the developed teaching materials was validated by three validators using validation sheets. The two validators were from academic institutions and one validator came from practitioner background. The validity refers to the measurement which shows the levels of validity or authenticity of a teaching material [21]. Validity has two important elements. First, validity shows a degree, some are perfect, moderate while others are low. Second, validity is always associated with a specific goal [22].

On the other hand, the practicality of a teaching material indicates the level of practicaliyu of a teaching material to be implemented in the learning process. The testing the practicality of teaching materials is measured by three aspects, namely: the implementation of the teaching materials, students' responses and teachers' responses to the teaching materials used. As for this study, practicality was only measured through the observation sheet on the implementation of the lesson plans for each meeting [23].

The effectiveness refers to the ability to achieve the desired goals [24]. A teaching material is said to be effective if it provides results which are in accordance with the objectives set by the researcher [25]. The effectiveness of learning is measured from the learning outcome tests (LOT) which are carried out by conducting pre-test and post-test. In addition, it is also measured based on the results of SPS observations. Determining the increase in students' cognitive learning outcomes test is done using the normalized gain (N-gain) equation. The normalized gain score obtained will be adjusted to the effectiveness criteria [26]. As for the results of SPS observations, the scores obtained are adjusted to the SPS assessment criteria adopted from the criteria for assessing academic proficiency [27].

\section{RESULTS AND DISCUSSIONS}

\section{Results of the Development of the Teaching Materials}

Teaching materials are utilized as a means to assist teachers in carrying out learning and teaching activities in the classroom. The developed teaching materials consist of materials, methods, limitations, and ways for evaluating, which are designed systematically and attractively to achieve the expected competencies [28].

The learner autonomy- oriented teaching materials developed include lesson plans, worksheets, topic materials, and learning outcome tests (LOT) for the topic of force and vibration motion which have previously been tested for their validity, practicality, and effectiveness. The teaching materials were arranged into three meetings with different learning models applied to each meeting, namely the direct instruction model for the first meeting, the guided inquiry model for the second meeting, and the group investigation type cooperative learning model for the third meeting.

\section{The Validity of the Teaching Materials}

The results of the validity test on the developed teaching materials can be observed in Table 1.

Table 1. The Teaching Materials Validity Test Results

\begin{tabular}{clcccc}
\hline \multirow{2}{*}{$\begin{array}{c}\text { Assessment Aspects of the } \\
\text { Teaching Materials }\end{array}$} & \multicolumn{2}{c}{ Validity } & \multicolumn{2}{c}{ Reliability } \\
\cline { 3 - 6 } & Sormulating Learning Objectives & 3.42 & Cery Valid & Score & Category \\
\hline \multirow{3}{*}{ Lesson } & Language & 3.22 & Valid & \\
Plan & Contents presented & 3.63 & Very Valid & 0.92 & High \\
& Duration & 3.11 & Valid & & \\
\hline
\end{tabular}




\begin{tabular}{clcccc}
\hline \multirow{2}{*}{$\begin{array}{c}\text { Assessment Aspects of the } \\
\text { Teaching Materials }\end{array}$} & \multicolumn{2}{c}{ Validity } & \multicolumn{2}{c}{ Reliability } \\
\cline { 3 - 6 } Topic & Content feasibility & Score & Category & Score & Category \\
\hline \multirow{3}{*}{ Materials } & Display feasibility & 3.49 & Very Valid & & \\
& Language feasibility & 3.44 & Very Valid & 0.90 & High \\
& Graphic feasibility & 3.27 & Valid & & \\
\multirow{3}{*}{ Worksheets } & Worksheet Format & 3.45 & Very Valid & & \\
& Language & 3.48 & Very Valid & & \multirow{2}{*}{ High } \\
& Worksheet Content & 3.17 & Valid & 0.88 & \\
\hline \multirow{5}{*}{ THB } & 3.33 & Valid & & \\
& Question number 1 & 3.27 & Valid & & \\
& Question number 2 & 3.22 & Valid & & \\
& Question number 3 & 3.29 & Valid & \multirow{2}{*}{0.84} & High \\
& Question number 4 & 3.31 & Valid & & \\
& Question number 5 & 3.24 & Valid & & \\
& Question number 6 & 3.60 & Very Valid & & \\
\hline
\end{tabular}

Table 1 displays that overall, based on the assessment aspects of the formulation of learning objectives, language, the content presented, and the duration, the lesson plans were categorized in the "valid" category. These results indicate that the development results of the lesson plans can be drawn to have met the components of a good lesson plan. This is also judged as accordance to the components contained in Permendikbud Number 22 in the year of 2016 concerning the Standardization of the Primary and Secondary Education Process. Additionally, the results of the development of this lesson plan can be used by other teachers as a guide to improve students' abilities throughout their learning process in accordance with the learning strategies used. Figure 2 below shows a small portion of the lesson plan products developed:

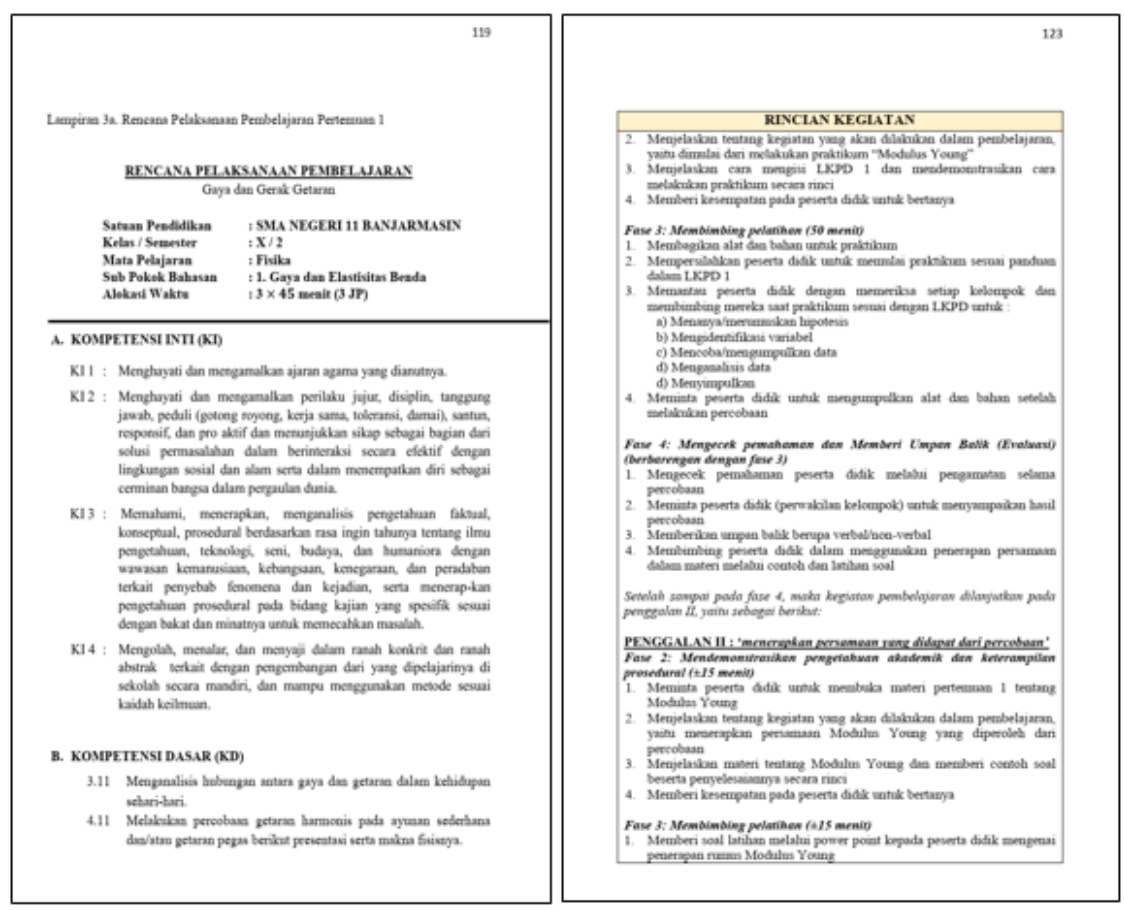

Fig 2. Lesson Plan Product

The first meeting discussed the topic of elasticity of objects which was taught using direct instruction model. The second meeting, on the other hand, discussed the subject of Hooke's Law using guided inquiry model, while the third meeting discussed harmonic motion with the use of cooperative learning type group investigation model. 
The lesson plan format referred to the 2013 Curriculum, consisting of core competencies, basic competencies, and basic competency achievement indicators which are grouped into product indicators and process indicators. Each point in the indicator is developed into several learning objectives. In addition, there are learning materials which contain important points from the topics studied.

The validity of the teaching materials in Table 1, based on the aspects of the assessment of the content feasibility, presentation, language, and graphics belonged in the "very valid" validity category, which meant that the teaching materials developed have met the requirements of qualified, good teaching materials which met the four elements of feasibility, namely content feasibility, presentation feasibility , linguistic feasibility, and graphic feasibility. The following Figure 3 displays a product of the developed teaching materials.
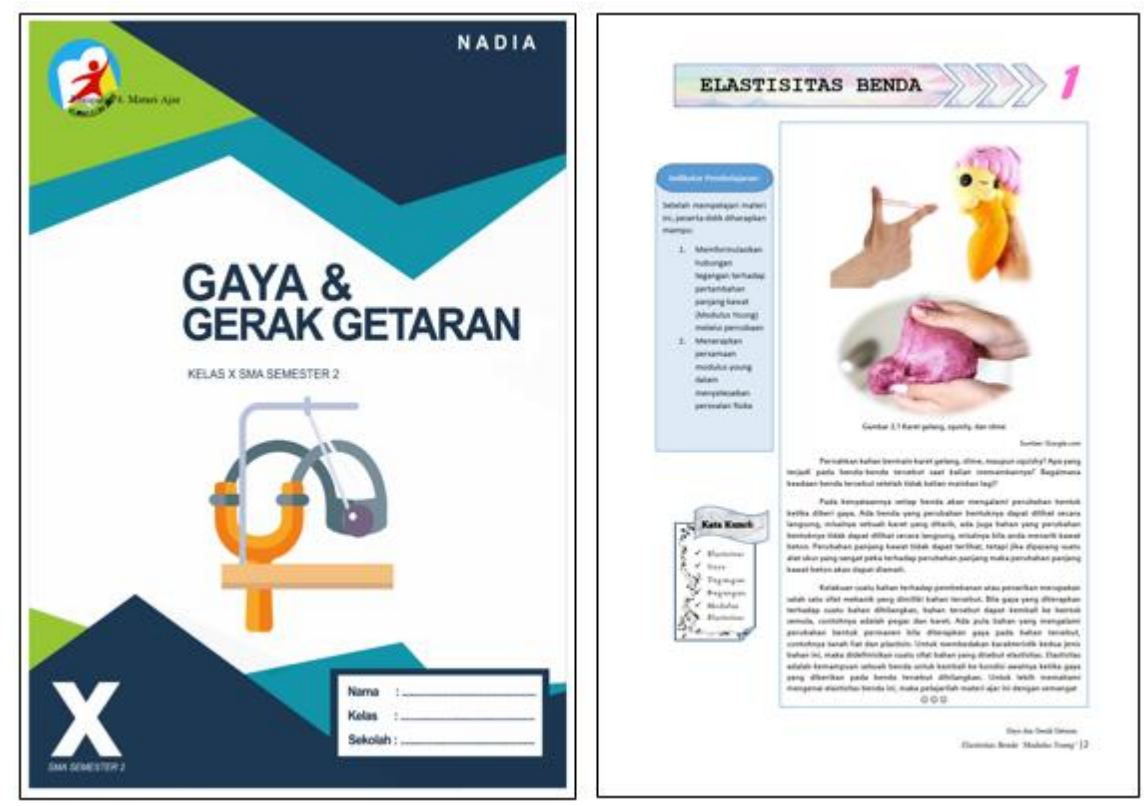

Fig 3. Finished Teaching Materials Product

The teaching materials are designed as a learning resource for students. The contents integrated within the developed teaching materials are adjusted to the learning objectives formulated in the lesson plan. Teaching materials are designed for three meetings, according to the sub-topics which will be discussed at each meeting. Even so, the topics are still combined in one book to ease the students in using the books as they were also given from the beginning of the meeting. This teaching material contains: (1) front cover; (2) preface; (3) table of contents; (4) instructions for the use of teaching materials for students along with the teaching material itself; (5) core competence, basic competence, learning indicators; (6) a text box in the page corner which says, "So, let's be a researcher!"; (7) concept map; (8) the beginning of the sub-topics to be studied which include the learning objectives, keywords, application illustrations, and introductory paragraphs that guide students to think and seek questions from phenomena that they can easily observe in their surroundings; (9) an elaboration of the materials; (10) special boxes which say, "Information Corner" and "Physics Figures"; (11) example question exercises; (12) scientific activities; (13) topic summary; (14) practice questions; and (15) glossary. The writing and arrangement of this teaching material is adjusted to the standards by Prastowo [29] which states that in making teaching materials, teachers must be innovative in providing learning support activities to students so that the achievement indicators can be achieved. This will help students to be active, creative and not easily bored during learning [30].

The teaching materials which were developed next were student worksheet. In Table 1 , it can be seen that the results of the student worksheet validation are categorized as valid so that they can be used in a research. As Akbar [31] stated, a valid student worksheet must meet several requirements in order to be 
deemed as "good", namely: (a) construction requirements, which refers to the use of appropriate language, proper sentence structure, vocabulary, level of difficulty, and clarity; (b) didactic requirements, such as regulating the use of universal worksheets so that it can be used properly for both slow and clever learners; (c) technical requirements, emphasizing on the presentation of the worksheets, such as in the form of writing, pictures and appearance. These aspects must be in good condition so that they can be tested in school [32].

The developed worksheet is a worksheet containing instructions and assignments as a guide for students in exploring the learning materials in order to achieve the learning objectives. There are three student worksheets which were developed to accommodate learning and teaching activities throughout the three meetings.
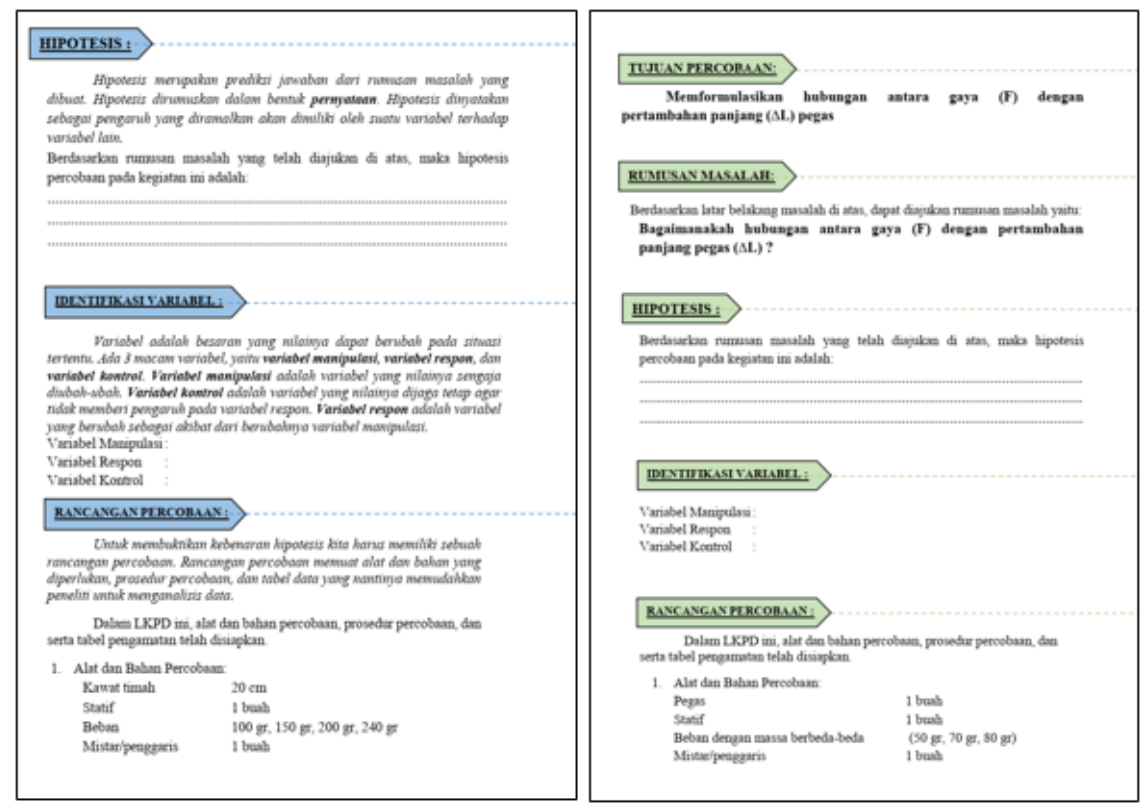

Fig 4. The Sections of the DI Model Worksheet for the First and Second Meeting
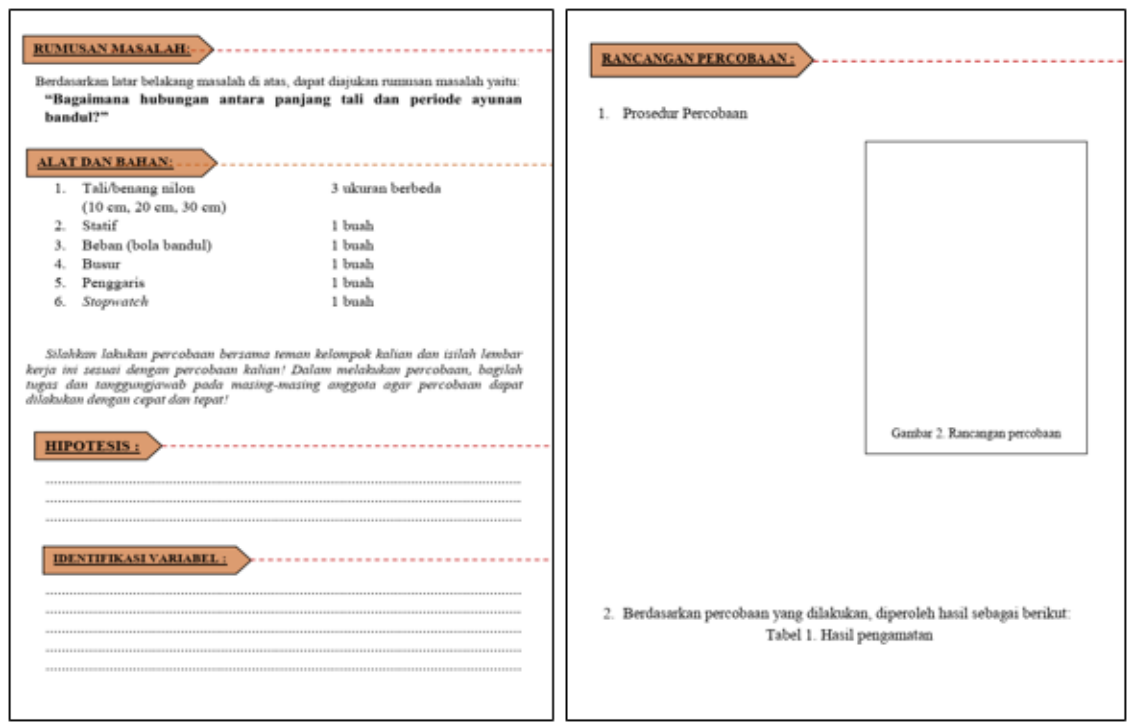

Fig 5. CL Model Type GI Worksheet for the Third Meeting

In the direct instruction (DI) learning model worksheet used, it is mainly dominated by clear instructions 
which are hoped to assist students in understanding them after reading thoroughly, considering that in the DI learning model, students are still provided with a lot of assistance from the teachers. In the worksheet for the second meeting which is based on Guided Inquiry learning model, instructions were still given and the information is not as detailed as the first meeting. Moreover, the role of the teacher in the classroom was reduced. In the worksheet distributed based on the group investigation (GI) type of cooperative learning model, only the worksheets of technical instructions were distributed, which included the information on the position of writing hypotheses, identifying variables, experimental design, etc. If in the previous worksheets, there were points which had been filled in by the teacher, such as the experimental step, the worksheet points in the GI model would be fully filled by students. The teacher only provided space to fill in. The worksheets given at this third meeting included two worksheets with different topics, namely pendulum swings and spring vibrations which are free to choose at the students' own wills and preferences.

LOT is a test prepared by teachers to measure and assess student learning outcomes, both on formative exams (daily tests) and summative exam [33]. The results of the THB validation average for each item were known to be in the valid category.

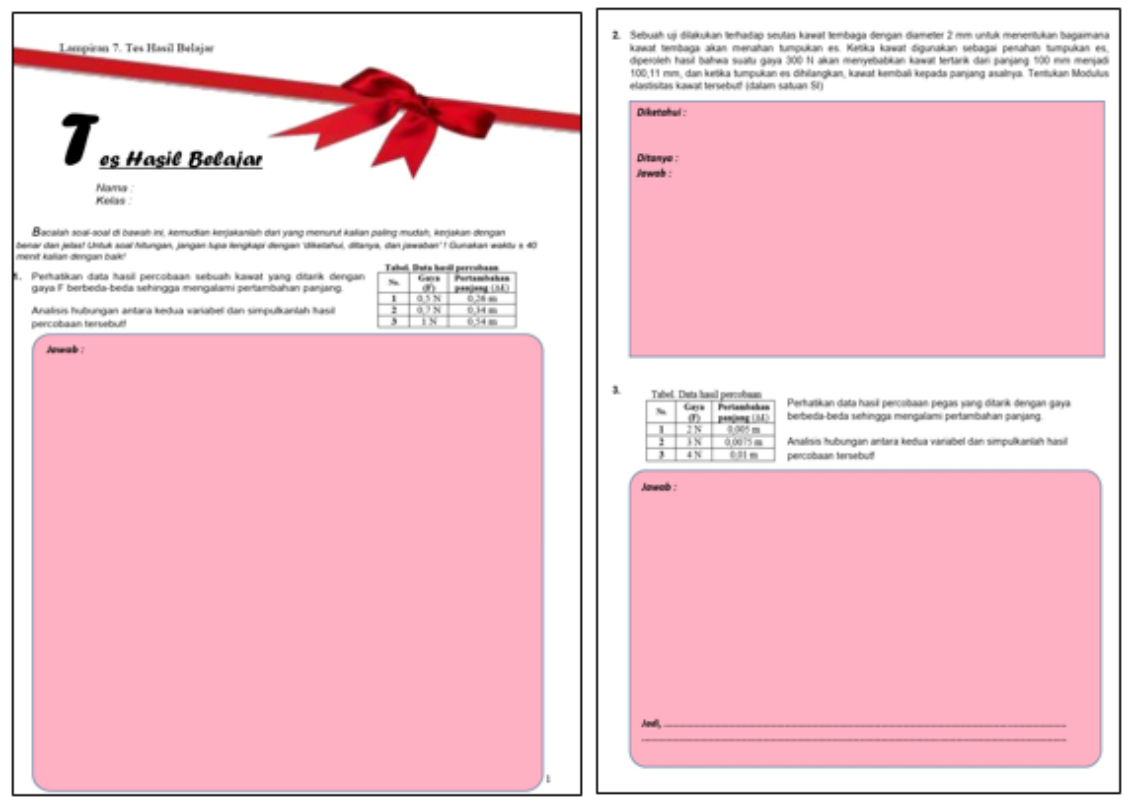

Fig 6. Finished Learning Outcome Test (LOT) Products

LOT consists of a collection of 6 essay items according to the number of objectives to be achieved. There are three sub-topics in the teaching material for force and vibration motion, namely elasticity, Hooke's law, and harmonic motion. Students are taught to be able to formulate equations and apply them to solve problems contained in the sub-topic.

Teaching materials which integrate the use of learner autonomy-oriented learning models in the subject of force and vibration movement received "valid" validity based on the mean score for the overall validity test of the developed teaching materials in the form of lesson plans, student worksheet, teaching materials, and LOT. It is generally known that teaching materials are said to be valid if they are included in the "good" / "valid" category [34], and thus, the teaching materials developed can be continuated at the product trial stage in the field.

Practicality of Teaching Materials

The results of the lesson plan implementation can be observed in Table 2. 
Table 2. The Observation Results of the Lesson Plan Implementation

\begin{tabular}{ccccc}
\hline \multirow{2}{*}{ Meeting } & \multicolumn{2}{c}{ Lesson Plan Implementation } & \multicolumn{2}{c}{ Reliability } \\
\cline { 2 - 5 } & Mean & Category & Score & Category \\
\hline 1 & 3.76 & Very Practical & 0.85 & High \\
2 & 3.63 & Very Practical & 0.62 & Moderate \\
3 & 3.63 & Very Practical & 0.93 & High \\
\hline
\end{tabular}

Purwanto [35] stated that in order to measure the practicality of the teaching materials to be developed in the study, the implementation of the lesson plans must be observed. Then, based on the observations on the lesson plans carried out as displayed in Table 2, all the lesson plan meetings 1, 2, and 3 indicate that they are categorized as "very practical". This shows that the learning steps in the lesson plans promote learner autonomy, and that it is comprehensible by learners and convenience to be used by other teachers as a guide in the classroom learning process [19]. Research by Zakiati, Mastuang and Suyidno [15] also said the learner autonomy teaching materials is easy to be used during learning process and is very helpful for both teacher and students.

\section{The Effectiveness of the Teaching Materials}

The effectiveness of the teaching materials is examined based on the results of the student learning outcomes. In this case, regarding the effectiveness of students' cognitive learning outcomes can be seen in Table 3.

Table 3. The Result of Students' Cognitive Learning Outcomes

\begin{tabular}{cccc}
\hline \multirow{2}{*}{ LOT Score } & \multicolumn{2}{c}{ Effectiveness } \\
\cline { 2 - 4 } & & N-gain & Category \\
\hline Pre-test & 6.10 & 0.67 & Moderate \\
Post-test & 69.19 & & \\
\hline
\end{tabular}

This effectiveness is observed based on the $\mathrm{N}$-gain acquisition. The pre-test results are required along with the post-test results to measure the gain score (N-gain) in their study, that the effectiveness of a learning process can be measured through the LOT results of the pre-test and post-test. This teaching material is deemed effective for improving students' cognitive abilities since the teaching materials provide satisfying results that are in accordance with the stated goals. The category of effectiveness associated with students' cognitive domain is obtained because of the use of learner autonomy-oriented physics teaching materials. To note, the teaching materials distributed to students are designed to be easy to use in the learning process, both in class and independently at home. Also, it is equipped with sample questions along with practice questions that can help students learn. The teaching material uses simple and communicative language, and is designed as attractive and colorful as possible, so that it is not boring when used [36]. The materials are printed in medium size so that it is easy to carry. There is actual information related to the material being taught, as well as additional information about science processing abilities which are highly needed by students in order to experiment properly and correctly. Moreover, it encourages students to obtain better grades. This is because the learner autonomy teaching material provide students an independence to build their own knowledge trough experiment so that the learning became meaningful [14], [15]. A meaningful learning will improve students' outcomes so the teaching materials will be effective [37].

The distribution of learner autonomy-oriented teaching materials can help teachers to train students' independence, so that they become more trained and independent to learn at every meeting. The effectiveness of this learner autonomy-oriented teaching material, based on the cognitive learning outcomes of the students, is categorized in the "moderate" category, so it is quite effective to utilize in the learning process. This is in accordance with a research conducted by Salam [14], which states that learner autonomy-based learning is able to promote student's activities that encourage learning autonomy. 


\section{Science Process Skills}

Practicing SPS is the main objective of this research. SPS is measured to determine the effect of using teaching materials as an effort to improve students' SPS. SPS is measured using the worksheets given at each meeting. The following Table 4 presents the results of students' SPS observations.

Table 4. The Result of Students' SPS Observation

\begin{tabular}{ccc}
\hline Observation Aspects & Mean & Category \\
\hline Formulating hypotheses & 81.9 & Very Good \\
Identifying variables & 70.8 & Good \\
Designing experimental procedures & 90.3 & Very Good \\
Experimenting / collecting data & 51.4 & Fair \\
Analyzing data & 59.7 & Fair \\
Drawing conclusions & 87.5 & Very Good \\
\hline Mean & & 73.6 \\
Category & & Good \\
\hline
\end{tabular}

Science process skill is carried out in several stages. Table 4 shows the average score of the students' SPS results for 3 meetings in each aspect of the SPS trained. The findings of this research are in accordance with Jean Piaget's learning theory, which says that children play an active role in the process of compiling their own knowledge of reality. During the first meeting, students fully learn under the supervision of the teacher. This is in accordance to the DI model which has unique characteristics in the form of activities to demonstrate (exemplify) knowledge / skills. Then, at the second meeting, students were given the opportunity to build their own knowledge with the teacher's involvement still existing. This second meeting utilized guided inquiry model. When compared to the previous meeting which used direct instruction model in which SPS demonstration was provided for students, in this second meeting, students were given more space to learn and practice SPS independently, even with the assistance of the teachers based on what was taught at the previous meeting. In the third meeting, students were demanded to play an active role in compiling their own knowledge, according to Piaget's theory. During the third meeting, an additional aspect was added to theskills to be trained, namely compiling experimental procedures. In average, all of the aspects which were trained for 3 meetings belonged in "good" category, which meant that there was an increase in the students' mastery of SPS after being taught using learner autonomy-oriented teaching materials.

This learner autonomy-oriented teaching material is designed not only to enhance students' cognitive abilities, but also to nurture their SPS. According to Salam [38], the essence of learner autonomy-based learning is to optimize students' initial knowledge in the process of building new knowledge. In optimizing this initial knowledge, the selection of a suitable and appropriate learning strategies or models must be adjusted to the students' level of experience as well as the characteristics of the materials taught. As a result, learner autonomy-based learning is not only focused on one learning model, but it can be adjusted to give greater responsibility to students and make the learning activities to be student centered. To improve students' SPS, in this learner autonomy-oriented learning, students are given worksheets which were designed according to the learning model applied at each meeting.

Based on the results of the study, the learner autonomy strategy utilized can aid students to enhance their science process skills. These results are in line with the results of research conducted by Salam et al [14] which states that teaching materials that are based on learner autonomy are effective for improving students' SPS. SPS will be easy to be improved if students are given a chance to enhace their skill by participating in learning [19]. After the application of teaching materials, the students are trained to improve their SPS in physics learning and independent enough to construct the knowledge wihout relying on teacher anymore. 


\section{CONCLUSION AND SUGGESTION}

Physics teaching materials which are learner autonomy oriented is suitable to help enhance students' science process skills on force and vibration motion materials in high school because they meet the criteria to be declared as valid, practical, and effective. This is supported by: a) the validity of the developed learner autonomy-oriented teaching materials obtained a certain mean score which is categorized as "valid"; b) the practicality of the developed learner autonomy-oriented teaching materials is categorized in "very practical" category; and c) the effectiveness of the developed learner autonomyoriented teaching materials observed based on students' cognitive learning outcomes tests with a moderate N-gain acquisition and students' SPS achievement in the "good" category.

Learner autonomy-oriented teaching materials to nurture SPS in the topics of force and vibration motion materials can be used as print-based learning resources to support the implementation of the 2013 Curriculum. However, further research and development should be carried out to explore the possibilities of this product, such as enhancing students' SPS on force and vibration motion materials or for other materials, as well as on the same materials to further improve existing ones. Last but not least, there is a dire need for assessment criteria to determine the level of students, so that teachers can decide which learning models are suitable for use in the subsequent learning activities.

\section{REFERENCES}

[1] Handayani, B. T., Arifuddin, M., \& Misbah, M. (2017). Meningkatkan keterampilan proses sains melalui model guided discovery learning. Jurnal Ilmiah Pendidikan Fisika, 1(3): 143-154.

[2] Sudrajat, A., Zainuddin, Z., \& Misbah, M. (2017). Meningkatkan Keterampilan Proses Sains Siswa Kelas X MA Muhammadiyah 2 Al Furqan Melalui Model Pembelajaran Penemuan Terbimbing. Jurnal Ilmiah Pendidikan Fisika, 1(2): 74-85.

[3] Komariah, U. H., Jamal, M. A., \& Misbah, M. M. (2017). Meningkatkan Keterampilan Proses Sains Melalui Model Inquiry Discovery Learning Terbimbing Pada Pokok Bahasan Fluida Statis Di Kelas XI IPA 4 SMAN 11 Banjarmasin. Berkala Ilmiah Pendidikan Fisika, 5(3): 309-327.

[4] Mahmudah, I. R., Makiyah, Y. S., \& Sulistyaningsih, D. (2019). Profil keterampilan proses sains (KPS) siswa SMA di Kota Bandung. DIFFRACTION, l(1).

[5] Aktamis, H., \& Ergin, Ö. (2008, June). The effect of scientific process skills education on students' scientific creativity, science attitudes and academic achievements. In Asia-Pacific forum on science learning and teaching (Vol. 9, No. 1, pp. 1-21). The Education University of Hong Kong, Department of Science and Environmental Studies.

[6] Nugraha, A. J., Suyitno, H., \& Susilaningsih, E. (2017). Analisis kemampuan berpikir kritis ditinjau dari keterampilan proses sains dan motivasi belajar melalui model pbl. Journal of Primary Education, 6(1): 35-43.

[7] Arifuddin, M., Aslamiah, M., Misbah, M., \& Dewantara, D. (2020, January). The implementation of guided inquiry model on the subject matter harmonious vibration. In Journal of Physics: Conference Series (Vol. 1422, No. 1, p. 012001). IOP Publishing.

[8] Ilma, S., Al-Muhdhar, M. H. I., Rohman, F., \& Saptasari, M. (2020). The correlation between science process skills and biology cognitive learning outcome of senior high school students. JPBI (Jurnal Pendidikan Biologi Indonesia), 6(1): 55-64.

[9] Choirunnisa, N. L., Prabowo, P., \& Suryanti, S. (2018, January). Improving Science Process Skills for Primary School Students Through 5E Instructional Model-Based Learning. In Journal of Physics: Conference Series (Vol. 947, No. 1, p. 012021). IOP Publishing.

[10] Dewi, E. P., Suyatna, A., Abdurrahman, A., \& Ertikanto, C. (2017). Efektivitas Modul dengan Model Inkuiri untuk Menumbuhkan Keterampilan Proses Sains Siswa pada Materi Kalor. Tadris: Jurnal Keguruan dan Ilmu Tarbiyah, 2(2): 105-110.

[11] Toharudin, U., Hendrawati, S., \& Rustaman, A. (2011). Membangun literasi sains peserta didik. Bandung: Humaniora. 
[12] Levy, P., \& Petrulis, R. (2012). How do first-year university students experience inquiry and research, and what are the implications for the practice of inquiry-based learning?. Studies in Higher Education, 37(1): 85-101.

[13] Hafizah, S., Miriam, S., \& Misbah, M. (2020). Meningkatkan Keterampilan Proses Sains Peserta Didik Pada Materi Elastisitas dan Hukum Hooke Berorientasi Learner Autonomy. Jurnal Ilmiah Pendidikan Fisika, 4(2): 76-88.

[14] Salam, A., Miriam, S., \& Misbah, M. (2017). Pembelajaran fisika berbasis learner autonomy dengan metode pemecahan masalah pada topik gelombang. Jurnal Sains dan Pendidikan Fisika, 13(3): 231-237.

[15] Zakiati, E., Mastuang, M., \& Suyidno, S. (2019). Feasibility of Learner Autonomy Oriented Physics Learning Material to Train Student's Science Process Skills. Berkala Ilmiah Pendidikan Fisika, 7(2): 105-114.

[16] Little, D. (1995). Learning as dialogue: The dependence of learner autonomy on teacher autonomy. System, 23(2): 175-181.

[17] Balçıanl1, C. (2010). Learner autonomy in language learning: Student teachers' beliefs. Australian Journal of Teacher Education, 35(1): 8.

[18] Wahyudi, W., \& Lestari, I. (2019). Pengaruh Modul Praktikum Optika Berbasis Inkuiri Terhadap Keterampilan Proses Sains dan Sikap Ilmiah Mahasiswa. Jurnal Pendidikan Fisika dan Keilmuan (JPFK), 5(1): 33-44.

[19] Fatmah, S. N., Mastuang, M., \& Salam, A. (2019). Pembelajaran Berbasis Learner Autonomy Topik Gelombang Cahaya Untuk Melatihkan Keterampilan Proses Sains. Vidya Karya, 33(2): 154162.

[20] Tegeh, I. M., Jampel, I. N., \& Pudjawan, K. (2014). Model Penelitian Pengembangan. Yogyakarta: Graha Ilmu.

[21] Arikunto, S. (2013). Prosedur Penelitian. Jakarta: Rineka Cipta.

[22] Arifin, Z. (2016). Evaluasi Pembelajaran. Bandung: PT Remaja Rosdakarya.

[23] Putri, N. W. S., \& Ardana, I. M. (2014). Pengembangan Perangkat Pembelajaran Tandur Berbantuan Geogebra Sebagai Upaya Meningkatkan Prestasi Dan Aktivitas Belajar Geometri Siswa. Jurnal Pendidikan dan Pembelajaran Matematika Indonesia, 3(1).

[24] Handoko, H. (2011). Manajemen Personalia \& Sumber Daya Manusia Edisi Kedua.

[25] Anisah, A., Wati, M., \& Mahardika, A. I. (2016). Pengembangan perangkat pembelajaran getaran dan gelombang dengan model inkuiri terstruktur untuk siswa kelas viiia smpn 31 banjarmasin. Berkala Ilmiah Pendidikan Fisika, 4(1): 1-12.

[26] Hake, R. R. (1998). Interactive-engagement versus traditional methods: A six-thousand-student survey of mechanics test data for introductory physics courses. American journal of Physics, 66(1): 64-74.

[27] Widoyoko, E. P. (2016). Evaluasi program pembelajaran. Yogyakarta: Pustaka Pelajar.

[28] Nurdyansyah, N. (2018). Pengembangan Bahan Ajar Modul Ilmu Pengetahuan Alambagi Siswa Kelas Iv Sekolah Dasar. Universitas Muhammadiyah Sidoarjo.

[29] Prastowo, A. (2015). Panduan Kreatif Membuat Bahan Ajar Inovatif. Yogyakarta: Diva Press.

[30] Misbah, M., Dewantara, D., \& Mahtari, S.(2018). Physics learning based on wetlands and banjar culture. International Journal of Applied and Physical Sciences, 4(1): 21-28.

[31] Akbar, S. (2016). Instrumen Perangkat Pembelajaran. Bandung: Remaja Rosdakarya.

[32] Anissa, R., Mastuang, M., \& Misbah, M. (2020). Efektivitas perangkat pembelajaran fisika bermuatan lingkungan lahan basah untuk melatihkan karakter waja sampai kaputing. JPFT (Jurnal Pendidikan Fisika Tadulako Online), 8(2).

[33] Zamsir, Z. (2010). Kualitas Tes Buatan Guru Matematika SLTP Negeri di Kota Madya Kendari. Jurnal Pendidikan Matematika dan Sains, 15(2): 65-69.

[34] Noor, M., Zainuddin, Z., \& Miriam, S. (2017). Pengembangan perangkat pembelajaran IPA fisika melalui model pengajaran langsung dengan metode problem solving. Berkala Ilmiah Pendidikan Fisika, 5(3): 328-339.

[35] Purwanto, N. (2013). Prinsip-Prinsip dan Teknik Evaluasi Pengajaran. Bandung: Remaja Rosda Karya.

[36] Sumiati, E., Septian, D., \& Faizah, F. (2018). Pengembangan modul fisika berbasis Scientific 
JIPF, Vol. 6 No. 3, September 2021

Approach untuk meningkatkan Keterampilan Proses Sains siswa. Jurnal Pendidikan Fisika dan Keilmuan (JPFK), 4(2): 75-88.

[37] Johnson, E. B. (2011). Contextual Teaching and Learning: Menjadikan Kegiatan Belajar Mengajar Mengasyikkan dan bermakna. Bandung: Kaifa.

[38] Salam, A. (2018). Teknik pemodelan fisika dalam setting pembelajaran berbasis learner autonomy. Jurnal Fisika Flux: Jurnal Ilmiah Fisika FMIPA Universitas Lambung Mangkurat, 15(1): 47-53. 